\title{
Effects of grazing and soil micro-climate on decomposition rates in a spatio-temporally heterogeneous grassland
}

\author{
Anita C. Risch • Martin F. Jurgensen • \\ Douglas A. Frank
}

Received: 19 March 2007 / Accepted: 21 June 2007 / Published online: 4 August 2007

(C) Springer Science + Business Media B.V. 2007

\begin{abstract}
Grazing and seasonal variation in precipitation and temperature are important controls of soil and plant processes in grasslands. As these ecosystems store up to $30 \%$ of the world's belowground carbon (C), it is important to understand how this variability affects mineral soil $\mathrm{C}$ pools/fluxes, and how $\mathrm{C}$ cycling might be affected by changes in precipitation and temperature, due to climate change. The aim of this study was to investigate the effects of grazing and differences in soil temperature and moisture on standard organic matter (OM) decomposition rates (cotton cloth) incubated in the top $10 \mathrm{~cm}$ soil of grasslands with variable topography in Yellowstone National Park (YNP) during the 2004 growing season. Grazing did not affect soil temperature,
\end{abstract}

Responsible Editor: Barbara Wick.

A. C. Risch - D. A. Frank

Department of Biology, Biological Research Laboratory,

Syracuse University,

130 College Place,

Syracuse, NY 13244, USA

A. C. Risch $(\bowtie)$

Swiss Federal Institute for Forest,

Snow and Landscape Research,

Zuercherstrasse 111,

8903 Birmensdorf, Switzerland

e-mail: anita.risch@wsl.ch

M. F. Jurgensen

Michigan Technological University,

School of Forest Resources and Environmental Sciences,

1400 Townsend Drive,

Houghton, MI 49931, USA moisture, cotton cloth decomposition rates, soil bulk density, soil $\mathrm{C}$ and $\mathrm{N}$ concentrations, or soil $\mathrm{C}: \mathrm{N}$ ratios. However, a large spatio-temporal variability in decomposition was observed: cotton cloth decomposition was positively related to soil moisture and soil $\mathrm{C}$ and $\mathrm{N}$ concentrations, and negatively to soil temperature. Highest decomposition rates were found in wetter slope bottom soils [season averages of decomposition given as rate of decomposition (cotton rotting rate $=\mathrm{CRR})=23-26 \%$ ] and lower rates in drier, hill-top soils (season averages, $C R R=20 \%$ ). Significantly higher decomposition rates were recorded in spring, early summer and early fall when soils were moist and cool (spring, $\mathrm{CRR}=25 \%$; early summer, $\mathrm{CRR}=26 \%$; fall, $\mathrm{CRR}=20 \%$ ) compared to midsummer $(C R R=18 \%)$ when soils were dry and warm. Our findings suggest that climate-change related decreases in precipitation and increases in temperature predicted for North American grasslands would decrease soil OM decomposition in YNP, which contrasts the general assumption that increases in temperature would accelerate OM decomposition rates.

Keywords Cotton strip · Grazing · Heterogeneity ·

Soil moisture - Soil temperature .

Standard organic material

\section{Introduction}

Grasslands are an important component of the global carbon (C) cycle, covering approximately one-third of 
the earth's terrestrial surface area (Lieth 1978), and storing between 10 and $30 \%$ of the world's soil C (Anderson 1991; Eswaran et al. 1993). Recently, there has been considerable interest in understanding factors that control $\mathrm{C}$ cycling in grassland ecosystems, as changes in precipitation and temperature related to climate change may alter $\mathrm{C}$ pools. Soil $\mathrm{C}$ turnover rates are a function of organic matter (OM) quality and quantity and soil micro-climatic (temperature and moisture), physical, chemical (texture, $\mathrm{pH}$, bulk density, C/nutrient concentrations) and biological (microbial biomass, composition, and diversity) properties (e.g., Epstein et al. 2002). The influence of soil temperature and moisture on $\mathrm{OM}$ and its decomposition will make soil $\mathrm{C}$ pools and processes sensitive to predicted future changes in climate (e.g., Jenkinson et al. 1991; Kirschbaum 1995; Bellamy et al. 2005). Large-scale evidence for this was recently provided by Bellamy et al. 2005, who proposed that climate change during a 25 year period (1978-2003) was responsible for soil C losses across England and Wales.

Many models that allow simulating the effect of climate and/or land use on grassland $\mathrm{C}$ dynamics have been developed during the past 60 years to better understand and predict changes in soil OM (for a recent overview see Shibu et al. 2006). As Smith et al. 1997 point out, such models embody our best understanding of soil $\mathrm{C}$ dynamics; however it is essential to evaluate them against field data. While considerable information on grassland $\mathrm{C}$ stores is available from soil surveys and inventories, field based data on decomposition rates mostly is from studies on turnover rates of surface litter (e.g., Shaw and Harte 2001; Koukoura et al. 2003; Smith and Bradford 2003). Considerably less information is available on OM decomposition in grassland soils.

Grassland is structurally and functionally heterogeneous habitat. Grassland soil temperature and moisture vary spatially, due to topo-edaphic gradients (e.g., Schimel et al. 1985; James et al. 2003), and temporally, due to seasonal changes in air temperature and precipitation (e.g., Lauenroth and Sala 1992; Briggs and Knapp 1995; Epstein et al. 2002; Knapp et al. 2002). These conditions create spatial variation in the amount (plant biomass) and quality (plant composition) of OM that is available to the soil decomposer food-web (e.g., Knapp et al. 1993; Briggs and Knapp 1995), and temporal variation in the microclimatic conditions suitable for biological activity. Thus, OM decomposition rates should be expected to vary considerably within grasslands. Yet, little is known about the spatio-temporal variation of, and the controls on soil decomposition rates in grassland ecosystems (Homann and Grigal 1996; Murphy et al. 1998; Epstein et al. 2002).

Large herbivores also can affect OM decomposition in grassland ecosystems. Grazing can alter the soil microclimate (temperature and moisture) by increasing the radiant energy reaching the soil leading to higher soil temperatures, and by reducing the transpirational surface area of the vegetation, which reduces the rate of soil moisture loss (McNaughton 1984, 1985; Seastedt et al. 1988). Grazing has also been shown to enhance soil N availability (Shariff et al. 1994, McNaughton et al. 1997, Frank and Groffmann 1998, Johnson and Matchett 2001), which can lead to changes in soil biological properties (e.g., microbial biomass, composition). Further, it has been reported that grazing can increase the plant $\mathrm{N}$ content (McNaughton 1984, Coughenour 1991, Shariff et al. 1994), and therefore the quality of the OM entering the soil. Despite these many-fold ways grazing could influence OM decomposition in grassland soils, most studies have either focused on how herbivores affect surface litter decomposition rates (e.g., Olofsson and Oksanen 2002; Wardle et al. 2002) or assessed grassland-grazer interactions on ecosystem properties and $\mathrm{OM}$ decomposition through modeling approaches (recent review in Tietjen and Jeltsch 2007). We could only find two field studies that investigated the effect of herbivores on soil OM decomposition rates in grassland (Shariff et al. 1994; Güsewell et al. 2005). More information on how large grazers affect soil OM decomposition rates will be needed to comprehensively understand the impact of these animals on $\mathrm{OM}$ processes.

The objective of our study was to assess how grazing, soil moisture and soil temperature affect OM decomposition of a standard OM (cotton cloth) in grasslands of Yellowstone National Park (YNP). By using a standard organic substrate, OM quality is held constant (lignin content, $\mathrm{C}: \mathrm{N}$ ratio, etc.) and decomposition becomes a function of soil micro-climatic, physical and chemical properties and the composition of the decomposer community (Berg 2000). 


\section{Materials and methods}

Study area

The study was conducted on the northern winter range of Yellowstone National Park (YNP), located in the northwestern corner of Wyoming, USA $\left(44^{\circ} 55^{\prime} \mathrm{N}\right.$ to $45^{\circ} 10^{\prime}$ and $110^{\circ} 10^{\prime} \mathrm{W}$ to $\left.110^{\circ} 50^{\prime} \mathrm{W}\right)$, and home to large migratory herds of elk (Cervus elaphus L.), bison (Bison bison L.), and pronghorn [Antilocarpa americana (Ord.)]. The northern winter range $(\sim 100,000 \mathrm{ha})$ is primarily comprised of grassland and shrub-grassland, and is inhabited by roughly 8,300 elks, 1,400 bison and 225 pronghorn (winter counts 2003/2004; Northern Yellowstone Cooperative Wildlife Working Group 1996-2004, P.J. White, R. Wallen personal communications). Elevations range from 1,600 to $2,200 \mathrm{~m}$ and the climate is fairly cool and dry, with mean annual temperatures and precipitation of $4.6^{\circ} \mathrm{C}$ and $379 \mathrm{~mm}$, respectively (NOAA, weather data). Soils of the northern winter range are mostly derived from glacial till of andesitic and sedimentary origin laid down during the Pleistocene (Keefer 1987).

\section{Sampling design}

We used three ungulate exclosures $(100 \times 200 \mathrm{~m})$ that were established by the Park Service between 1958 and 1962 at Mammoth Hot Springs, Junction Butte and Lamar Valley. We established a total of five study sites at these three exclosures at locations where we could find good paired sites that included a wide range of topographic positions encompassing hill-top, slope and slope-bottoms. Two sites were located at the Mammoth exclosure (site 1, site 5), one at Junction Butte (site 2), and two at Lamar (site 3, site 5). The Mammoth and Lamar exclosures were approximately $48 \mathrm{~km}$ apart and the Junction Butte exclosure was roughly midway between those two. Elevation differences between the three exclosures did not exceed $250 \mathrm{~m}$. The two study sites at the Mammoth and Lamar exclosures were separated by approximately $200 \mathrm{~m}$ and were considered spatially independent. The five sites varied in topography: sites 1 and 2 were located at dry hill tops, site 3 on a dry slope and sites 4 and 5 were located at relatively mesic slope bottoms. Detailed site descriptions are provided in
Table 1. Soils at all sites were classified as Mollisols according to the USDA keys to soil taxonomy (Soil Survey Staff 2003).

At each of the sites we established a set of paired plots $(15 \times 15 \mathrm{~m})$ inside (ungrazed) and outside (grazed) the exclosure. The paired plots were established in grassland vegetation and had the same aspect, slope, and dominant plant species. Plots were located at least $5 \mathrm{~m}$ away from the fence to avoid a fence effect. Green and dead biomass were nondestructively measured in all the plots as described in detail by Risch and Frank 2006. Green biomass was considerably higher at sites 4 and 5 compared to the three other sites (Table 1), but did not differ in grazed and ungrazed grassland (Risch and Frank 2006). The percentage of vegetation cover at sites 1,2 and 3 was approximately $50 \%$, and over $90 \%$ at sites 4 and 5 (A. Risch, personal observation).

Ungulates were observed at each site throughout the 2004 sampling season (A. Risch, personal observations). Data on consumption rates of large ungulates are not available for the 2004 growing season. For the period 1999 to 2001, however, Frank (2007) reported that biomass consumed by large herbivores across topographically variable grassland averaged between $37 \pm 6($ mean \pm SE) and $60 \pm 16 \mathrm{~g} / \mathrm{m}^{2}$.

Soil physical and chemical parameters: sampling and analyses

Five soil samples were randomly taken with a core sampler (core diameter, $2 \mathrm{~cm}$ ) to a depth of $10 \mathrm{~cm}$ in each plot in July 2004, dried to constant weight at $60^{\circ} \mathrm{C}$, passed through a $2 \mathrm{~mm}$ sieve and then analyzed for soil texture (hygrometer method) and soil $\mathrm{pH}(2: 1$ water-soil paste; Table 1). Five additional soil samples were randomly taken in each plot with a core sampler (core diameter $2 \mathrm{~cm}$ ) to a depth of $10 \mathrm{~cm}$ in July 2004 after removing plant parts and surface plant litter $\left(\mathrm{O}_{\mathrm{i}}\right.$ horizon). We decided to include the organic $\mathrm{O}_{e}$ and $\mathrm{O}_{\mathrm{a}}$ horizons (if developed) in our $0-10 \mathrm{~cm}$ sampling depth, as they are an important factor in soil OM decomposition processes. Each of the soil samples was dried to constant weight at $60^{\circ} \mathrm{C}$, passed through a $2 \mathrm{~mm}$ sieve, and analyzed for total $\mathrm{C}$ and nitrogen (N) with a CE Instruments NC 2100 soil analyzer (CE Elantech Inc., Lakewood NJ, USA). Sub-samples of each soil sample were further dried at $105^{\circ} \mathrm{C}$ to 
determine soil bulk densities, which were calculated based on the total dry weight and the volume of the sample. Soil temperature $(10 \mathrm{~cm}$ depth $)$ and moisture (0-10 cm depth) were measured with permanently installed sensors (Onset Computer, Bourne, MA, USA) in each grazed and ungrazed plot during the entire growing season.

Decomposition rates of standard material

We used a cotton strip assay (Latter and Howson 1977; Latter and Walton 1988) to assess the effect of grazing, soil moisture, and soil temperature on standard OM decomposition rates across the YNP landscape during the 2004 growing season. Cotton cloth tensile strength loss (CTSL) is a measure of decomposition, and can be used as an index to express the combined effect of soil microclimatic, physical, chemical and biological properties on $\mathrm{OM}$ decomposition (e.g., Latter and Walton 1988; Sagar 1988; Withington and Sanford 2007). Beginning in May 2004, five $20 \times 10 \mathrm{~cm}$ sheets of $100 \%$ unbleached cotton cloth obtained from Daniel Jenny \& Co., Switzerland (specifications of cotton cloth: American Type SM 1/18", Warp: 34/1, Weft: 20/1, Weave plain, 29.5 picks $/ \mathrm{cm}$ warp, 22 picks $/ \mathrm{cm}$ weft, $237 \mathrm{~g} / \mathrm{m}^{2}$ ) were inserted vertically into the soil of each plot by making a slit with a flat spade to a depth of $10 \mathrm{~cm}$, inserting the cloth with the spade, and then pushing the slit closed with the spade to assure tight contact of cloth with soil. Deeper placement of the cloth than $10 \mathrm{~cm}$ was not possible due to the high rock content of the topsoil at most sites. The cloths were retrieved after one month and new sheets were installed and removed at monthly intervals from midMay through mid-September (further referred to "May/June", “June/July", "July/August”, “August/ September" sampling periods). Five control cloths (same fabric as the incubated cloth) also were inserted at all the plots (grazed and ungrazed) each time a new set of cloths were incubated (monthly) and immediately removed in order to estimate CTSL from the insertion process.

After retrieval, the cloths were air-dried, the remaining soil gently removed, and $1 \mathrm{~cm}$ wide strips containing the same number of cotton threads were cut at the 4.5 to $5.5 \mathrm{~cm}$ soil depth. The strips were equilibrated at $50 \%$ relative humidity and $20^{\circ} \mathrm{C}$ for $48 \mathrm{~h}$ prior to strength testing on a Scanpro Awetron TH-1 tensile strength 
tester (AB Lorentzen aand Wettre, Kista, Sweden). Cotton tensile strength loss was calculated as

$$
\mathrm{CTSL}=\mathrm{CTS}_{\text {control }}-\mathrm{CTS}_{\text {final }}
$$

where $\mathrm{CTS}_{\text {control }}$ is the cotton tensile strength of the control cloth and $\mathrm{CTS}_{\text {final }}$ the cotton tensile strength of the incubated sample. The rate of cotton decay (cotton rotting rate $=\mathrm{CRR}$ ) was then calculated according to the function derived by Hill et al. 1985:

$$
\mathrm{CRR}=\left(\mathrm{CTSL} / \mathrm{CTS}_{\text {final }}\right)^{1 / 3} *(365 / t)
$$

where $t$ is the incubation period length in days. This function linearizes the curvilinear response for tensile strength loss, and allows between site comparisons (Hill et al. 1985).

\section{Statistical analyses}

Grazing effects on CRR, soil moisture, and soil temperature were analyzed with paired $t$-tests for each sampling period (May/June, June/July, July/ August, August/September) separately. Grazing effects on bulk density, $\mathrm{C}$ and $\mathrm{N}$ concentrations, and $\mathrm{C}: \mathrm{N}$ ratios of the top $10 \mathrm{~cm}$ soil also were analyzed with paired $t$-tests. To assess the relationships between soil microclimatic variables and CRR, we used linear regression analyses with soil moisture and soil temperature as independent, and CRR as the dependent variables. Data for soil moisture were arc-sine square root transformed in order to meet the normality assumption. Regression analysis also was used to assess the relationship between soil temperature and soil moisture, as well as between CRR and the amount of $\mathrm{C}$ and $\mathrm{N}$ stored in the soil. To analyze how CRR, soil moisture and soil temperature differed in space and time (between-site, between-month), we normalized the data using

$$
\mathrm{y}_{\mathrm{norm}, i}=\frac{y_{i}}{\sqrt{\sum_{i=1}^{n} y_{i}^{2}}}
$$

to remove seasonal effects for between-site comparisons and spatial effects for between-month comparisons, respectively (where $y_{i}$ represent the non-normlized (raw) data and $y_{\text {norm, } i}$ the normalized data; Quinn and Keough 2002). We then used the normalized data to perform a one-way analysis of variance, followed by a LSD post-hoc test for pairwise comparison (alphalevel $=0.1$ ) to assess how CRR, soil moisture and soil temperature changed across the landscape (site was independent, and normalized CRR, normalized soil moisture and normalized soil temperature were the dependent variables). To test how CRR, soil moisture and soil temperature changed over the course of the growing season, we used repeated-measure analyses of variance followed by a pairwise LSD post-hoc test (month was independent, and normalized CRR, normalized soil moisture and normalized soil temperature were the dependent variables).

\section{Results}

Grazing effects on decomposition of standard OM and soil properties

Long-term exclusion of large ungulates did not have any effect on CRR, soil moisture or soil temperature at any time of measurement throughout the 2004 growing season in YNP ( $p$ values of $t$-tests for pairwise comparisons all $>0.05, n=5$ for all tests). Because soil bulk density, soil $\mathrm{C}, \mathrm{N}$ concentrations, and soil $\mathrm{C}: \mathrm{N}$ ratios in $0-10 \mathrm{~cm}$ soil depth also did not differ between inside and outside of the exclosures ( $p$ values of $t$-test for pairwise comparison all $>0.05, n=5$ for all tests), the data from grazed and ungrazed grassland plots were averaged for each site for further analyses (Table 2).

Relationships between decomposition rates of standard OM and soil properties

Cotton cloth decomposition rates were significantly and positively correlated with soil moisture (Fig. 1a) and the $0-10 \mathrm{~cm}$ soil $\mathrm{C}(p=0.02, n=5)$ and $\mathrm{N}(p=0.02, n=5)$ contents. Soil moisture, $\mathrm{C}$, and $\mathrm{N}$ content all co-varied with one another $(p<0.001$ for all comparisons). We also found a negative relationship between CRR and soil temperature (Fig. 1b), which was weakly negatively correlated (exponential decay function) with soil moisture (Fig. 1c). Temperature especially affected soil moisture at the dry, hill-top sites, while close to no effect of temperature was detected for the wetter, slopebottom sites (Fig. 1c). No correlation was detected 
Table 2 Bulk density, C, N and C:N ratios for the top $10 \mathrm{~cm}$ of soil [after removing plant parts and surface plant litter $\left(\mathrm{O}_{\mathrm{i}}\right.$ horizon)]

\begin{tabular}{|c|c|c|c|c|c|c|c|c|}
\hline \multirow[t]{2}{*}{ Site } & \multicolumn{2}{|c|}{ Soil bulk density $\left(\mathrm{Mg} \mathrm{cm}^{-3}\right)$} & \multicolumn{2}{|l|}{ Soil C (\%) } & \multicolumn{2}{|l|}{ Soil N (\%) } & \multicolumn{2}{|c|}{ Soil C:N ratio } \\
\hline & Ungrazed & Grazed & Ungrazed & Grazed & Ungrazed & Grazed & Ungrazed & Grazed \\
\hline 1 & $1.2(0.06)$ & $1.2(0.02)$ & $4.7(0.3)$ & $3.8(0.3)$ & $0.40(0.03)$ & $0.31(0.03)$ & $11.5(0.05)$ & $11.4(0.28)$ \\
\hline 2 & $1.1(0.13)$ & $1.4(0.05)$ & $3.0(0.4)$ & $3.1(0.4)$ & $0.25(0.04)$ & $0.30(0.03)$ & $12.0(0.35)$ & $10.2(0.15)$ \\
\hline 3 & $0.9(<0.01)$ & $1.0(0.10)$ & $4.3(0.5)$ & $4.3(0.4)$ & $0.42(0.04)$ & $0.42(0.04)$ & $10.2(0.17)$ & $10.2(0.15)$ \\
\hline 4 & $1.1(0.04)$ & $1.0(0.10)$ & $9.6(0.4)$ & $9.5(1.2)$ & $0.89(0.03)$ & $0.82(0.08)$ & $10.8(0.23)$ & $11.5(0.31)$ \\
\hline 5 & $0.5(0.13)$ & $0.7(0.08)$ & $17.3(0.4)$ & $20.0(0.8)$ & $1.30(0.04)$ & $1.60(0.07)$ & $13.7(0.08)$ & $12.3(0.39)$ \\
\hline
\end{tabular}

No variable was significantly different between grazed and ungrazed grassland ( $p$ value $t$-test for pairwise comparison $>0.05$ ) Standard errors in parentheses, $n=5$ for all variables. 1 Mammoth Hot Springs, hill-top; 2 Junction Butte, hill-top; 3 Lamar Valley, slope; 4 Lamar Valley, slope bottom; 5 Mammoth Hot Springs, slope bottom.

between soil temperature and soil $\mathrm{C}$ and $\mathrm{N}$ concentrations (C: $p=0.13, n=5 ; \mathrm{N}: p=0.12, n=5)$.

Spatio-temporal differences in decomposition rates of standard OM

Cotton cloth decomposition $(p<0.001)$, soil moisture $(p<0.001)$, and soil temperature $(p=0.002)$ differed significantly across the landscape. Cotton cloth decomposition was fastest at site 5 , where highest soil $\mathrm{C}$ and soil moisture values $(20.3 \%)$ were found (Fig. 2a, site 5), compared to decomposition in hilltop and slope soils (sites 1,2,3), which had less $\mathrm{C}$ in the soil and were drier (4.7 to $7.0 \%$ moisture). Spatial differences in soil temperature were relatively small $\left(13.9-16^{\circ} \mathrm{C}\right)$ compared to differences in soil moisture (4.7-20.3\%). However, significantly higher soil temperatures were detected at the exposed hill-top site (site 1), which had sparse vegetation and was located at the lowest elevation compared to the other four sites.

We also detected significant differences in CRR $(p<0.001)$, soil moisture $(p=0.004)$, and soil temperature $(p=0.001)$ over the course of the 2004 growing season. Cotton cloth decomposed fastest in spring (May/June) and early summer (June/July, Fig. 2b), when soils were moist (11.0 and $10.1 \%$ across site averages) and cool $\left(12\right.$ and $\left.16^{\circ} \mathrm{C}\right)$. These decomposition values significantly differed from the much lower mid-summer (July/August) rates, when CRR was lowest due to warmer $\left(18^{\circ} \mathrm{C}\right)$ and drier (7.9\%) soils compared to spring and early summer conditions. In early fall (August/September), CRR was again significantly higher than in mid-summer (July/August: moisture $9 \%$, temperature $13^{\circ} \mathrm{C}$ ), but remained significantly below spring and early summer rates (Fig. 2b). Precipitation was higher in spring and fall, compared to mid-summer in both 2003 and 2004 (Fig. 3), and was similar to soil moisture trends observed during the 2004 growing season (data shown above).

\section{Discussion}

Grazing effects on standard OM decomposition

Grazing did not affect CRR, soil moisture and soil temperature measured in YNP during the 2004
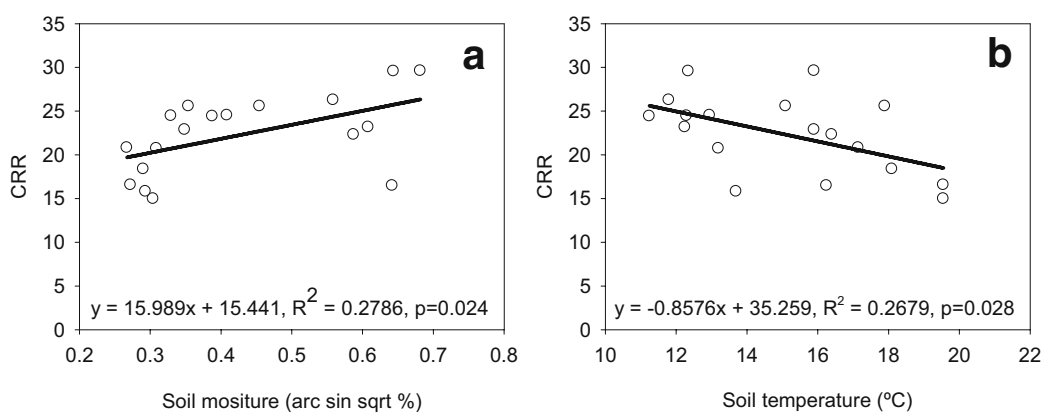

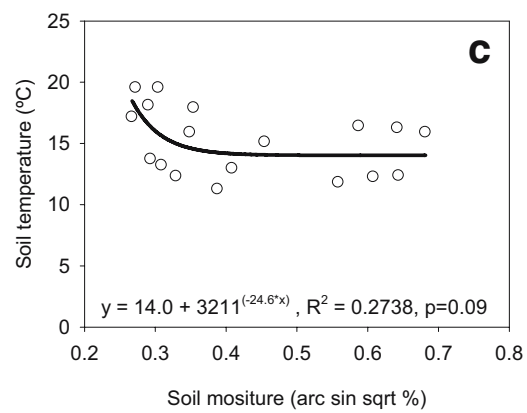

Fig. 1 Changes in CRR (cotton rotting rate), soil moisture and soil temperature across the Yellowstone National Park landscape during the 2004 growing season: a relationship between
CRR and soil moisture, $\mathbf{b}$ relationship between CRR and soil temperature, c relationship between soil moisture and soil temperature, $n=18$ for all three graphs 


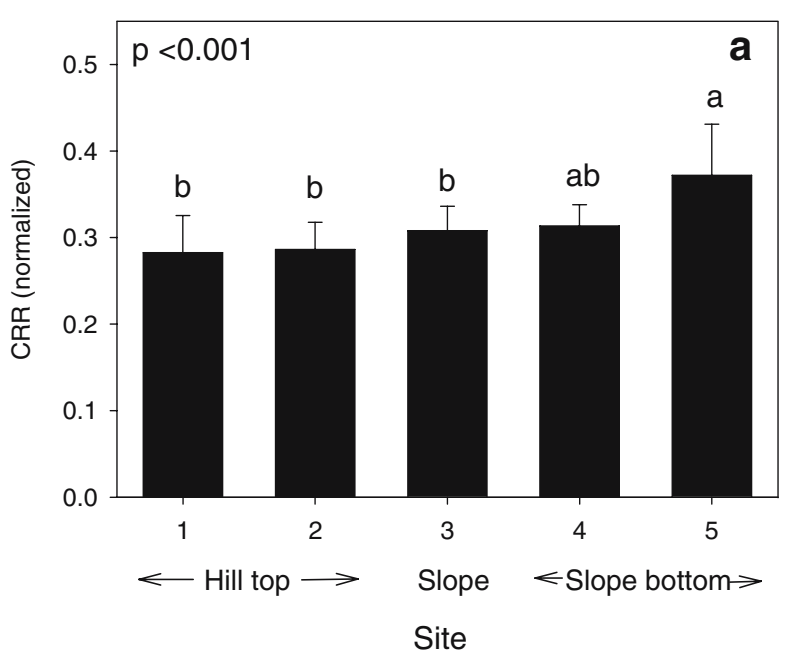

Fig. 2 Spatio-temporal variability in CRR (cotton rotting rate, normalized data): a) between-site differences (see Table 1) in CRR, and b) between-months differences in CRR. Different letters indicate significant differences between sites and months,

growing season. Studies conducted in other ecosystems have reported that by removing transpirational, shade-casting plant surface area herbivores can increase soil moisture and temperature (McNaughton 1984, 1985; Seastedt et al. 1988), which should lead to higher decomposition rates in grazed compared to ungrazed grassland. The likely reason for not finding such grazing-related differences in soil microclimate and CRR in our study could be related to compensatory responses of the vegetation, resulting in the same amount of standing biomass inside and outside exclosures in 2004 (Risch and Frank 2006).

We could find only two studies that investigated the impact of grazing on OM turnover rates in grassland soils. Shariff et al. 1994 reported higher root decomposition under moderate livestock grazing in soils of a North Dakota (USA) prairie compared to heavy and ungrazed treatments. The opposite result was found by Güsewell et al. 2005, who reported higher plant litter decomposition rates in the soil of heavily grazed cattle pastures in southern Switzerland, as compared to pastures that were lightly grazed. However, both papers suggested that decomposition was controlled by changes in litter and/or root $\mathrm{N}$ concentrations under different grazing pressures, but they did not provide any information on soil moisture or soil temperature conditions. LeCain et al. 2000, 2002, in contrast, investigated how soil moisture changed under different grazing regimes; but did not

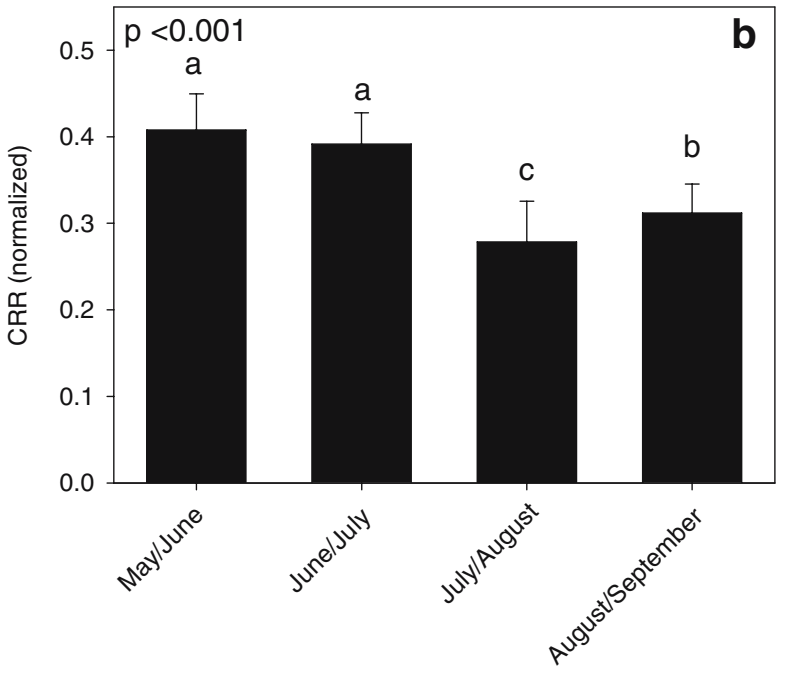

respectively, based on a LSD test for pair-wise comparison (alpha-level=0.1). 1=Mammoth Hot Springs, hill-top; $2=$ Junction Butte, hill-top; 3=Lamar Valley, slope; 4=Lamar Valley, slope bottom; $5=$ Mammoth Hot Springs, slope bottom

study decomposition processes. In these two studies, they found higher soil moisture in an ungrazed Wyoming, USA cattle pasture than in a grazed one (LeCain et al. 2000), and higher soil moisture in a heavily-grazed compared to a lightly-grazed pasture in Colorado, USA (LeCain et al. 2002). In Wyoming these results were attributed to a mulching effect by the accumulated litter and standing dead material inside the cattle exclosures, while in Colorado soil textures were different between the heavily- and lightly-grazed pasture. In a tall-grass prairie in Oklahoma (USA), Wan and Luo 2003 found significant short-term increases in soil temperature after simulating grazing by clipping as self-shading by the vegetation was reduced; but clipping did not consistently increase soil temperature and soil moisture over a one-year period (June 2001 to June 2002).

In our study, we also found no effect of large herbivores on soil bulk density, $\mathrm{C}$ and $\mathrm{N}$ concentrations or $\mathrm{C}: \mathrm{N}$ ratios. These results are similar to findings by Raiesi and Asadi 2006, who reported no differences in soil bulk density or $\mathrm{C}$ and $\mathrm{N}$ concentrations $(0-30 \mathrm{~cm})$ in domestic livestock-grazed rangeland in Iran. Also Augustine and Frank 2001 did not find any consistent differences in soil $\mathrm{C}$ and $\mathrm{N}$ from grazed and ungrazed long-term grassland exclosures in Yellowstone National Park. In contrast, light grazing by cattle in the high-plain grasslands of Wyoming, USA increased $\mathrm{C}$ and $\mathrm{N}$ stored in the top 
Fig. 3 Monthly precipitation totals measured at the weather stations Mammoth Hot Springs, Tower Falls, and Lamar ranger station for the years 2003 and 2004 (NOAA, weather data). Lamar ranger station data is only collected during the winter months (NovemberApril), therefore the May through October values are not available. Weather stations at Mammoth Hot Springs, Tower Falls, and Lamar Valley were within 2 $\mathrm{km}$ of the sites and therefore likely best reflect precipitation rates at sites $1 / 5,2$, and $3 / 4$, respectively

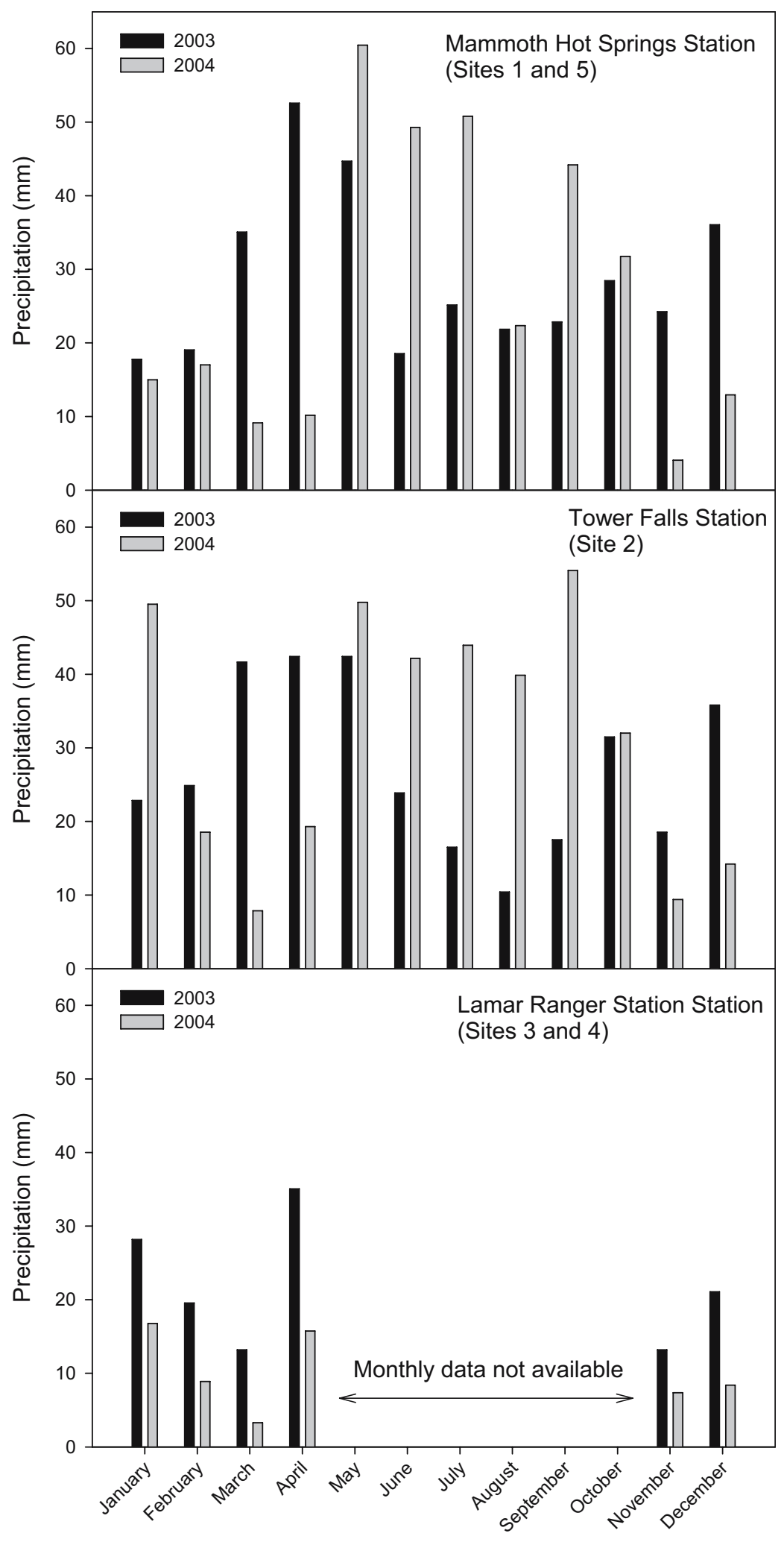

Month 
$5 \mathrm{~cm}$ of soil compared to heavy or no grazing (Ganjegunte et al. 2005). Bison grazing in tall-grass prairie of Kansas, USA, also had a positive effect on soil N content (Johnson and Matchett 2001). Topography affected the impact of elk grazing in the Rocky Mountain National Park, Colorado, USA, where soil bulk density, soil $\mathrm{C}, \mathrm{N}$ and nutrient concentrations were higher outside compared to inside the exclosures on slope bottoms, while no effects were detected on mid-slope and upland sites (Binkley et al. 2003).

Overall, the information available in the literature on how large herbivores influence soil properties shows that the effect of large mammals on these variables is highly dependent on the ecosystem studied and the grazing intensity that a particular ecosystem receives. As summarized in a recent review by Bardgett and Wardle 2003, positive effects of herbivory on soil biota and soil processes are generally found when soil fertility and grazing intensity are high within an ecosystem, while negative effects are to be expected in unproductive systems with low consumption rates.

Spatio-temporal differences in standard OM decomposition rates

Soil moisture and temperature have been shown to be drivers of soil $\mathrm{C}$ and $\mathrm{N}$ concentrations in grassland ecosystems and are generally included as interactive factors controlling decomposition rates in global $\mathrm{C}$ cycling models (see Shibu et al. 2006). Soil moisture, which seemed to be closely related to total amount of precipitation measured in YNP, was positively correlated to CRR in our study, while soil temperature had a negative effect. Soil temperature had a negative effect on soil moisture in the driest (hill-top) soils, where the cover of the vegetation was also lowest. There was no correlation between temperature and moisture for the wetter, slope-bottom soils. By inference then, the negative relationship between temperature and CRR may have been a function of temperature limiting soil moisture, the primary determinant of CRR in YNP, in dry grassland. Similar to our results, Homann and Grigal 1996 found a negative correlation between soil temperature and filter paper decomposition studied between May and July along transects containing abandoned field and prairie patches in Minnesota (USA). They attributed these results to a high inverse correlation between soil moisture and soil temperature, but did not measure soil moisture levels. However, our results are in contrast to other studies conducted in mineral soil of forest, tundra and agricultural grassland ecosystems, where positive interactions between temperature and decomposition rates of standard $\mathrm{OM}$ material in mineral soil were found (e.g., Ineson et al. 1988; Hopkins et al. 1990; Jurgensen et al. 2006, Drewnik 2006, Withington and Sanford 2007). These latter studies were conducted in ecosystems where soil moisture was usually not limiting for OM decomposition, while in dry ecosystems, such as the grasslands in our study, changes in soil moisture likely were more important for an alteration of OM decomposition rates than temperature. Also, in a study that used a regional data set of aboveground primary production, soil organic $\mathrm{C}$, soil texture, and climate to evaluate the environmental controls on decomposition rates throughout the US Great Plains, Epstein et al. 2002 suggested that temperature might be less important than moisture for $\mathrm{OM}$ decomposition in grassland ecosystems. They found a lack of correlation between air temperature and decomposition rates, which was modeled using net primary production and soil $\mathrm{OM}$ pools. Water was assumed to be the primary limiting factor in grassland ecosystems, although soil moisture data were not available. Similarly, Smith et al. 2005, when they modeled changes in soil organic C of European crop- and grasslands between 1990 and 2080, found that temperature only accelerated decomposition where soil moisture was not limiting.

In summary, our results showed that soil moisture was the primary control on cotton cloth decomposition in YNP grassland, with temperature only playing an indirect influence by modifying soil moisture levels at dry sites. We therefore would expect that climate change-related decreases in precipitation and increases in temperature predicted for water-limited ecosystems, such as grasslands of YNP (IPCC 2001), will lead to lower OM turnover rates and higher soil $\mathrm{C}$ storage. This scenario strongly contrasts the general assumption that increasing temperatures will lead to increases in OM decomposition (e.g., Kirschbaum 1995). Field studies such as the one we conducted in YNP are important to better understand the interactions between decomposition rates of $\mathrm{OM}$ material, soil temperature and soil moisture in grassland system and are needed if we were to better understand the effects of future climate change on their $\mathrm{C}$ sink-source relationships. 
Acknowledgements We thank Jessica Gale, Sara Taylor, Eric Weiss, Timothy DePriest, Anna Stewart, Michelle Niemelä and the USDA Forest Service Laboratory in Moscow, Idaho for their assistance in the field and laboratory work, Martin Schütz and the anonymous reviewers for constructive comments on the manuscript. We are grateful for the support by the Yellowstone National Park Service administration. This project was funded by US-NSF grant DEB-0318716, Swiss-NSF fellowships PBEZ-104320 and PBEZA-104320 and the vegetation-soils subproject of the Swiss-NFI.

\section{References}

Anderson JM (1991) The effects of climate change on decomposition processes in grassland and coniferous forests. Ecol Appl 1:326-347

Augustine DJ, Frank DA (2001) Effects of migratory grazers on spatial heteogeneity of soil nitrogen properties in a grassland ecosystem. Ecology 82:3149-3162

Bardgett RD, Wardle DA (2003) Herbivore-mediated linkages between aboveground and belowground communities. Ecology 84:2258-2268

Bellamy PH, Loveland PJ, Bradler RI, Lark RM, Kirk GJ (2005) Carbon losses from all soils across England and Wales 1978-2003. Nature 437:245-248

Berg B (2000) Litter decomposition and organic matter turnover in northern forest soils. For Ecol Manag 133:13-22

Binkley D, Singer F, Kaye M, Rochelle R (2003) Influence of elk grazing on soil properties in Rocky Mountain National Park. For Ecol Manag 185:239-247

Briggs JM, Knapp AK (1995) Interannual variability in primary production in tallgrass prairie: climate, soil moisture, topographic position, and fire as determinants of aboveground biomass. Am J Bot 82:1024-1030

Coughenour MB (1991) Biomass and nitrogen responses to grazing of upland steppe in Yellowstone's northen winter range. J Appl Ecol 28:71-82

Drewnik M (2006) The effect of environmental conditions on the decomposition rat of cellulose in mountain soils. Geoderma 132:116-130

Epstein HE, Burke IC, Lauenroth WK (2002) Regional patterns of decomposition and primary production rates in the U.S. Great Plains. Ecology 83:320-327

Eswaran H, van den Berg E, Reich P (1993) Organic carbon in soils of the world. Soil Sci Soc Am J 57:192-194

Frank DA (2007) Drought effects on above- and belowground production of a grazed temperate grassland ecosystem. Oecologia 152:131-139

Frank DA, Groffmann PM (1998) Ungulate vs landscape control of soil $\mathrm{C}$ and $\mathrm{N}$ processes in grasslands of Yellowstone National Park. Ecology 79:2229-2241

Ganjegunte GK, Vance GF, Preston CM, Schuman GE, Ingram LJ, Stahl PD, Welcker JM (2005) Soil organic carbon composition in a Northern mixed-grass prairie: effects of grazing. Soil Sci Soc Am J 69:1746-1756

Güsewell S, Jewell PL, Edwards P (2005) Effects of heterogeneous habitat use by cattle on nutrient availability and litter decomposition in soils of an Alpine pasture. Plant Soil 268:135-149
Hill MO, Latter PM, Bancroft G (1985) Standard curve for inter-site comparison of cellulose degradation using the cotton strip method. Can J Soil Sci 65:609-619

Homann P, Grigal DF (1996) Below-ground organic carbon and decomposition potential in a field-forest glacial-outwash landscape. Biol Fert Soils 23:207-214

Hopkins DW, Ibrahim IM, O’Donnell AG, Shiel RS (1990) Decomposition of cellulose, soil organic matter and plant litter in a temperate grassland soil. Plant Soil 124:79-85

Ineson PP, Bacon PJ, Lindley DK (1988) Decomposition of cotton strips in soil: analysis of the world data set. In: Harrison AF, Latter PM, Walton DWH (eds) Cotton strip assay: an index for decomposition in soils. Institute of Terrestrial Ecology, Grange-Over-Sands, England, pp 155-165

IPCC (2001) Intergovernmental Panel on Climate Change. Third assessment report

James SE, Pärtel M, Wilson SD, Peltzer DA (2003) Temporal heterogeneity of soil moisture in grassland and forest. J Ecol 9:234-239

Jenkinson DS, Adams DE, Wild A (1991) Model estimates of $\mathrm{CO} 2$ emissions from soil in response to global warming. Nature 351:304-306

Johnson LC, Matchett JR (2001) Fire and grazing regulate belowground processes in tallgrass prairie. Ecology 82:3377-3389

Jurgensen M, Reed D, Page-Dumroese D, Laks P, Collings A, Mroz G, Degorski M (2006) Wood strength loss as a measure of decomposition in northern forest mineral soil. Europ. J Soil Biol 42:23-31

Keefer WR (1987) The geological story of Yellowstone National Park. Yellowstone library and Museum Association, Mammoth, WY

Kirschbaum MUF (1995) The temperature dependence of soil organic matter decomposition, and the effect of global warming on soil organic $\mathrm{C}$ storage. Soil Biol Biochem 27:753-760

Knapp AK, Fahnestock TH, Hamburg SJ, Statland LB, Seastedt TR, Schimel DS, (1993) Landscape patterns in soil-plant water relations and primary production in tallgrass. Ecology 74: 549-560

Knapp AK, Fay PA, Blair JM, Collins SL, Smith MD, Carlisle JD, Harper CW, Danner BT, Lett MS, McCarron JK (2002) Rainfall variability, carbon cycling and plant species diversity in a mesic grassland. Science 298:2202-2205

Koukoura Z, Mamolos AP, Kalburtji KL (2003) Decomposition of dominant plant species litter in semi-arid grassland. Appl Soil Ecol 23:13-23

Latter PM, Howson G (1977) The use of cotton strips to indicate cellulose decomposition in the field. Pedobiologia 17:145-155

Latter PM, Walton D (1988) The cotton strip assay for cellulose decomposition studies in soil: history of the assay and development. In: Harrison AF, Latter PM, Walton DWH (eds) Cotton strip assay: an index for decomposition in soils. Institute of Terrestrial Ecology, Grange-Over-Sands, England, pp 7-9

Lauenroth WK, Sala OE (1992) Long-term forage production of North American shortgrass steppe. Ecol Appl 2:397-403

LeCain DR, Morgan JA, Schuman GE, Reeder JD, Hart RH (2000) Carbon exchange rates in grazed and ungrazed pastures of Wyoming. J Range Manag 53:199-206 
LeCain DR, Morgan JA, Schuman GE, Reeder JD, Hart RH (2002) Carbon exchange and species composition of grazed pastures and exclosures in the short-grass steppe of Colorado. Agric Ecosyst Environ 93:421-435

Lieth H (1978) Pattern of primary productivity in the biosphere. Hutchinson \& Ross, Stroudsberg, PA

McNaughton SJ (1984) Grazing lawns: animals in herds, plant form, and coevolution. Am Nat 124:863-886

McNaughton SJ (1985) Ecology of a grazing ecosystem: the Serengeti. Ecol Monogr 55:259-295

McNaughton SJ, Banyikawa FF, McNaughton MM (1997) Promotion of the cycling of diet-enhancing nutrients by African grazers. Science 278:1798-1800

Murphy KL, Klopatek JM, Klopatek CC (1998) The effects of litter quality and climate on decomposition along an elevational gradient. Ecol Appl 8:1061-1071

Northern Yellowstone Cooperative Wildlife Working Group (1996-2004) Annual reports 1996 to 2004

Olofsson J, Oksanen L (2002) Role of litter decomposition for the increased primary production in areas heavily grazed by reindeer: a litter bag experiment. Oikos 9:507-515

Quinn GP, Keough MJ (2002) Experimental design and data analysis for biologist. Cambridge, Cambridge, p 537

Raiesi F, Asadi E (2006) Soil microbial activity and litter turnover in native grazed and ungrazed rangelands in a semiarid ecosystem. Biol Fertil Soils 43:76-82

Risch AC, Frank DA (2006) Carbon dioxide fluxes in a spatially and temporally heterogeneous temperate grassland. Oecologia 147:291-302

Sagar BF (1988) The Shirley soil burial test fabric and tensile testing as a measure of biological breakdown of textiles. In: Harrison AF, Latter PM, Walton DWH (eds) Cotton strip assay: an index for decomposition in soils. Institute of Terrestrial Ecology, Grange-Over-Sands, England, pp 11-16

Schimel D, Stillwell MA, Woodmansee RG (1985) Biogeochemistry of $\mathrm{C}, \mathrm{N}$ and $\mathrm{P}$ in a soil catena of the short-grass steppe. Ecology 66:276-283

Seastedt TR, Ramundo RA, Hayes DC (1988) Maximization of densities of soil animals by foliage herbivory: empirical evidence, graphical, and conceptual models. Oikos 51: 243-248

Shariff AR, Biondini ME, Grygiel CE (1994) Grazing intensity effects on litter decomposition and soil nitrogen mineralization. J Range Manag 47:444-449

Shaw MR, Harte J (2001) Control of litter decomposition in a subalpine meadow-sagebrush steppe ecotone under climate change. Ecol Appl 11:1206-1223

Shibu ME, Leffelaar PA, Van Keulen H, Aggarwal PK (2006) Quantitative description of soil oranic matter dynamics - a review of approaches with reference to rice-based cropping systems. Geoderma 137:1-18

Smith VC, Bradford MA (2003) Litter quality impacts on grassland litter decomposition are differently dependent on soil fauna across time. Appl Soil Ecol 24:197-203

Smith P, Powlson DS, Smith JU, Elliot TE (1997) Evaluation and comparison of soil organic matter models using longterm datasets. Geoderma 81:1-255

Smith J, Smith P, Wattenbach M, Zaehle S, Hiedere R, Jones RJA, Montanarella L, Rounsevelle MDA, Reginster I, Ewert F (2005) Projected changes in mineral soil carbon of Europan croplands and grasslands, 1990 2080. Glob Change Biol 11:2141-2151

Soil Survey Staff (2003) Keys to soil taxonomy, 9th edn. U.S. Department of Agriculture, Natural Resources Conservation Service. Washington, DC: U.S. Govt. Print. Office, p 332

Tietjen B, Jeltsch F (2007) Semi-arid grazing systems and climate change: a survey of present modelling potential and future needs. J Appl Ecol 44:425-434

Wan S, Luo Y (2003) Substrate regulation of soil respiration in a tallgrass prairie: results of a clipping and shading experiment. Global Biogeochem Cycl 17:1054-1065

Wardle DA, Bonner KI, Barker GM (2002) Linkages between plant litter decomposition, litter quality and vegetation responses to herbivores. Funct Ecology 16:585-595

Withington CL, Sanford RL Jr (2007) Decomposition rates of buried substrates increase with altitude in the forest-alpine tundra ecotone. Soil Biol Biochem 39:68-75 